\title{
CMSERK GENE IS EXPRESSED IN RESPONSE TO THE ATTACK OF PATHOGEN FUNGI COLLETOTRICHUM ACUTATUM AND BOTRYTIS CINEREA
}

Paola Rivera ${ }^{1}$, Jacqueline Rojas ${ }^{1}$, Lorenzo Concia $^{2}$ and Augusta Y. Cueva-Agila ${ }^{1 *}$

${ }^{1}$ Departamento de Ciencias Biológicas, Universidad Técnica Particular de Loja, Loja, Ecuador.

${ }^{2}$ Department of Biology and Biotechnology. Pavia University, Pavia, Italy

`Autor para correspondencia: aycueva@pucesi.edu.ec

Recibido: 2020/11/02

Aprobado: 2021/05/23

DOI: https://doi.org/10.26621/ra.v1i24.688

\section{ABSTRACT}

The genus Cattleya groups orchids originate in tropical zones of South and Central America. One of the most representative species of ornamental importance is Cattleya maxima Lindl. In this study the fungal pathogens Colletotrichum acutatum and Botrytis cinerea were isolated and their pathogenicity was determined by in vitro inoculation of Cattleya maxima. Pathogenicity tests resulted positive for infection with $C$. acutatum after seven days of inoculation while as for $B$. cinerea the symptoms of infection appeared after two days. Quantitative PCR revealed that CmSERK gene is more expressed in tissue under fungal attack. These results suggest that CmSERK gene plays an important role in the activation of defense-related responses.

Keywords: Cattleya maxima, Colletotrichum acutatum, Botrytis cinerea, Quantitative PCR, SERK

\section{RESUMEN}

Las orquídeas del género Cattleya se originan en zonas tropicales de América del Sur y Central. Una de las especies de importancia ornamental más representativas es Cattleya maxima Lindl. En este estudio se aislaron los patógenos fúngicos Colletotrichum acutatum y Botrytis cinerea y se determinó su patogenicidad mediante inoculación in vitro de Cattleya maxima. Las pruebas de patogenicidad resultaron positivas para la infección por $C$. acutatum después de siete días de inoculación, mientras que para $B$. cinerea los síntomas de la infección aparecieron después de dos días. La PCR cuantitativa reveló que el gen CMSERK se expresa más en el tejido bajo ataque de hongos. Estos resultados sugieren que el gen CmSERK juega un papel importante en la activación de respuestas relacionadas con la defensa.

Palabras clave: Cattleya maxima, Colletotrichum acutatum, Botrytis cinerea, PCR cuantitativa, SERK 


\section{INTRODUCCIÓN}

Plants are sessile organisms that synthesize sugars through the photosynthesis and, such as, It is the preferential target for a wealth of pathogenic microorganisms. To counteract this constant threat, plants have evolved both non-host-specific protection systems, like the secretion of antimicrobial molecules and the presence of cutin and cell walls acting as physical barriers, and host-specific mechanisms that trigger a defense response in presence of pathogens (Bigeard, Colcombet and Hirt, 2015). The latter mechanism is mediated by outer membrane pattern recognition receptors (PRRs) able to recognize pathogen-associated or microbe-associated molecular patterns (PAMPs/MAMPs) as well as damage-associated molecular patterns (DAMPs) due to the pathogens' attack (Wan et. al, 2019).

The sensing of pathogens induces the PAMP-triggered immunity or pathogen-triggered immunity (PTI), a major physiological adaptation and transcriptional shift aimed at contrasting the pathogens' aggression that they include the closure of stomata, the deposition of callose, the productions of ethylene and reactive oxygen species (ROS) (Wu, Shan and $\mathrm{He}, 2014)$.

Many receptor-like-kinases (RLKs) play an important role in cell metabolism leading to growth and defense response for activating a large number of gene expression. The Somatic Embryogenesis Receptor Kinase (SERK) gene is claimed to have an important role. SERK gene was first isolated from carrot embryogenic cells, hailed as a molecular marker for somatic embryogenesis (Schmidt et al., 1997). Some studies have revealed that deletion of the SERK gene expression increased the susceptibility to pathogenic microbial attack (Santos et al. 2008).

Through molecular studies (OSSERK overexpression) has been shown that the resistance genes encode components of the host immune system, which confer the ability to recognize and respond to pathogens ( $\mathrm{Hu}$ et al., 2005). For Andean orchids SERK gene has been characterized in two species Cyrtochilum loxense, a native orchid (Cueva et al., 2012), and Cattleya maxima (Cueva-Agila et al., 2020) an epiphytic orchid which is distributed in Colombia, Ecuador and the northern Peru (Dodson et al., 2004). However, SERK gene expression has been studied only during the process of somatic embryogenesis. Studies on the role of the gene in response to attack by pathogens have not been performed in any species of orchid until now.

In the development orchids of fungi pathogens as Botrytis cinerea and Colletotrichum acutatum is favored by the presence of weak tissues and injury in plants (Wit, 2007). C. acutatum (teleomorph Glomerella acutata) is a pathogen which may be latent within the host tissues for a short or long period of time, caused the anthracnose. This is a holonecrotic disease that It is affecting all organs which limited commercial production of various important fruit crops. C. gloeosporiodes and C. acutatum are both categorized as species complexes, and contain a diverse array of species (Cannon et al. 2012).

Botrytis cinerea (teleomorph Botryotinia fuckeliana), also known as gray mold, is a pathogen that penetrates through wounds and dying foliage causing significant damage in crops such as vegetables and ornamentals. The characteristic symptoms of the disease are grayish mildew on fruits; and, in leaf can be observed necrosis around the point of contact being able to enter into the rest of the leaf if conditions are favorable for the fungus (Latorre et al. 1997).
Plants have developed multi defense strategies against infections that allow recognition of specific pathogens; this early recognition is one of the keys that activate the effective defense response.

The objective of this study was to know the CMSERK gene expression pattern in response to the attack of fungal pathogens Botrytis cinerea and Colletotrichum acutatum in order to have more information about the functionality of this gene in other plant processes for orchids.

\section{METHODS}

\section{Biological material: morphological and molecular identification}

Fungus samples were collected from tree tomato (Solanum betaceum) and strawberry (Fragaria vesca) with symptoms of Colletotrichum acutatum and Botrytis cinerea respectively.

The fruit surface was disinfected with alcohol $70 \%$ for 30 seconds, $1 \%$ sodium hypochlorite for 1 minute, rinsed two times with sterile water and then dried in filter paper. Fruit pieces of $3 \times 3 \mathrm{~mm}$ were plated onto sterilized potato dextrose agar (PDA) medium and incubated in dark in an inverted position at $250 \mathrm{C}$ during 10 days. Growing edges of any fungal colony from tissues were then transferred aseptically to new PDA plates. Monosporic isolates were performed to ensure the authenticity and purity of both fungi.

The macroscopic characteristics as shape and color of the fungal cultures were reviewed after ten days of incubation; as well as the morphological characters, including colony type, were reviewed after 1 to 3 weeks. The culture purity was checked through microscopic visualization as well as the shape of conidias with the Giemsa technique (Prihastuti et al. 2009),

In order to do the molecular identification, fungi DNA was extracted from macerated mycelium, using the DNeasy Plant Mini Kit from Qiagen $(\mathbb{a}$ according to the manufacturer's protocol. The quality of the extracted DNA was determined and verified by electrophoresis in $1 \%$ agarose gel and by spectrophotometry in Nanodrop 2000. PCR amplification was performed with universal primers ITS1 (5'-TCCGTAGGTGAACCTGCGG-3 ') and ITS4 (5'-TCCTCCGCTTATTGATATGC -3') (White et al. 1990) for C. acutatum and B. cinerea. In addition, the. MS547 specific primers (5'-AAGGAGGACGTTGGAAGGAT-3') / (5'-AAGTCCAGAATC TCGATGTATTTGT-3 '), encoding the ATP-dependent RNA helicase DBP7 were used to verify the identity of $B$. cinerea from $B$. pseudocinerea, a kind of Botrytis with similar morphological characteristics (Walker et al. 2011). The amplification reaction was performed in an Applied Biosystem thermocycler in $20 \mu \mathrm{L}$ final volume, containing $2 \mu \mathrm{L}$ of fungal DNA, $0.4 \mu \mathrm{L}$ of each primer, $0.8 \mu \mathrm{L}$ of BSA, $10 \mu \mathrm{L}$ Phusion polymerase mix and $6.4 \mu \mathrm{L}$ of sterile deionized distilled water to complete the final volume. For ITS gene the mixture was denatured at $980 \mathrm{C}$ for 30 seconds; following by 30 cycles at 98 oC for 10 seconds, $60 \mathrm{oC}$ for 20 seconds and $72 \mathrm{OC}$ for 30 seconds; and one final cycle at $720 \mathrm{C}$ for 7 minutes. For ATP-dependent RNA helicase DBP7 gene amplified only in $B$. cinerea, the mixture was denatured at $95 \mathrm{OC}$ for 5 minutes; following 40 cycles at $95 \mathrm{oC}$ for 30 seconds, $62 \mathrm{OC}$ for 30 seconds and 72 oC for 90 seconds; one final cycle at 72 oC for 5 minutes. The amplification products were verified in $1 \%$ agar gel through electrophoresis at $128 \mathrm{~V}, 300 \mathrm{~mA}$ for 20 minutes.

The PCR products were cloned using bacterial strains TOP10 of E. coli and Zero Blunt TOPO cloning kit (Invitrogen), according to the manu- 
facturer's instructions. Eight colonies were taken and purified using the S.N.A.P. TM MidiPrep Kit (Invitrogen). In order to verify positive colonies, enzymatic digestion was made using the restriction enzyme EcoR1.

Electrophoresis was performed in 1\% agarose gel to observe the product. Plasmid DNA purified was sequenced using Applied Biosystems 3500 Genetic Analyzer; universal primers M13-Fw (5'TGT AAA ACG ACG GCC AGT3') and M13-Rv (5'TGC CAG GAA ACA GCT ATG AC3') were used. The sequences obtained were compared with GenBank database in $\mathrm{NBCl}$ (http://blast.ncbi.nlm.nih.gov/Blast.cgi) using the BLASTn algoritm (Altschup et al. 1990).

\section{In vitro inoculation of Cattleya maxima Lindl plants with pa- thogenic fungi}

Healthy in vitro 8-month-old plants of Cattleya maxima maintained on Murashige \& Skoog (MS) medium were inoculated with a fungal suspension of $1 \times 106$ spores $/ \mathrm{ml}$ of $C$. acutatum and $B$. cinerea. The spore inoculation was performed in the adaxial part of two leaves (apex) per each plant. Inoculation of distilled water was used as negative control. Ten plants were used for the spore and the inoculation control. The plants were placed in a growth chamber with proper incubation conditions for the fungi development: temperature $19^{\circ} \mathrm{C}$, humidity $18 \%$, under photoperiod of $16 \mathrm{~h}$ light and 8 hours' darkness.

To determine the presence of symptoms of the disease: the following variables was observed on the external leave surface: period and latency period, time of spot appearance, necrosis or invasion of the fungus to the whole plant.

\section{RNA extraction, cDNA synthesis and PCR Tubulin}

Three healthy and 3 infected plants were selected using four samples (apexes) for RNA extraction. Each sample was stored at $-80{ }^{\circ} \mathrm{C}$ until RNA extraction. RNA was extracted using the kit Plant RNeasy Mini (Qiagen) following the manufacturer's instructions. Each RNA sample was analyzed by electrophoresis in $1 \%$ agarose gel. The cDNA synthesis was performed by preparing a mix solution with 10 $\mu$ l of 2x RT Buffer, $1 \mu \mathrm{l}$ of 20x RT Enzyme (Applied Biosystem) and 9ul of RNA, obtaining a fi-

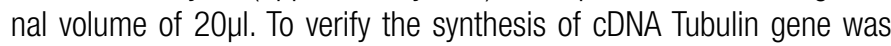
amplified using the following primers: Tubulin_Onc_Hou_Fw: 5'-GGATTAGGCTCTCTGCTGTTGG-3' and Tubulin_Onc_Hou_Rv: 5'-GTGTGGATAAGACGCTGTTGTATG3' (Hou and Yang, 2009). PCR was performing in a mixture of: $10.05 \mu \mathrm{l}$ of sterile deionized distilled water, $4 \mu \mathrm{l}$ of Buffer, 1.6 $\mu \mathrm{l}$ of $\mathrm{MgCl} 2,1 \mu \mathrm{l}$ of Fw Tubulin primer, $1 \mu \mathrm{l}$ of Rv Tubulin primer, $0.3 \mu \mathrm{l}$ of dNTPs, $0.05 \mu$ l of GoTAQ and $2 \mu$ l of cDNA, obtaining a final volume of $20 \mu$ l per sample. The mixture was denatured at $950 \mathrm{C}$ for 5 minutes; following by 34 cycles at $950 \mathrm{C}$ for 30 seconds, $580 \mathrm{C}$ for 40 seconds and $720 \mathrm{C}$ for 60 seconds; one final cycle at $720 \mathrm{C}$ for 5 minutes. Each sample was analyzed by electrophoresis in 1\% agarose gel.

\section{Real - Time quantitative PCR}

Real time PCR analysis was performed using the Fast SYBR $®$ Green Master Mix (Applied Bisystems) following the manufacturer's protocol. For each sample (two healthy and two infected) it was performed a mix with: $10 \mu \mathrm{l}$ of Master Mix, $1 \mu \mathrm{l}$ of each primer, $6 \mu \mathrm{l}$ of $\mathrm{H} 20$ dde and $2 \mu \mathrm{l}$ of cDNA, obtaining a final volume of $20 \mu$ l. Three biological replicates of each sample were used and each one was setup in double. The relative expression was performed in an Applied Biosystems 7500 Fast Team Real-Time PCR System. To normalize the expression levels of SERK gene we used as reference the $\propto$ Tubulin gene employing the primers designed on an Oncidium species (Hou and Yang 2009). The specific CMSERK primers and PCR conditions used was the same detailed in Cueva-Agila et al. 2020. The analyses of the obtained data were performed with the LingReg program (Pfaffl, 2001).

\section{RESULTS AND DISCUSSION}

\section{Morphological and Molecular identification}

The monosporic isolates were analyzed to look for the morphological characteristics. The $C$. acutatum isolates presented a mycelium of a cottony white color. The conidias were cylindrical, elongated of orange/salmon color, with pointed ends, these characteristics are similar to those reported for Colletotrichum acutatum by Walker et al. 2011 (Fig.1).

In contrast $B$. cinerea presented a gray mycelium, long branched conidiophores with conidia oval and globose (Fig.2), corresponding to Botrytis cinerea morphology, similar to that observed by Barnett and Hunter (1998) and Domsch et al. (2007).
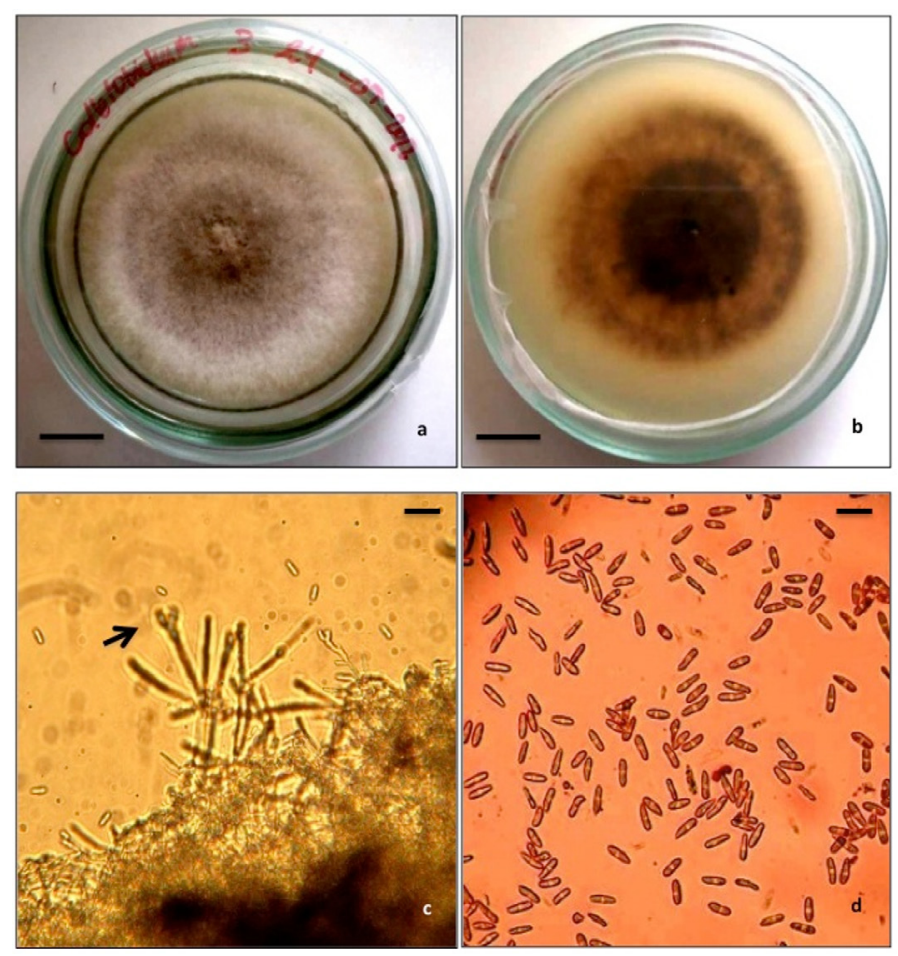

Figure 1. Morphologic structure of $C$. acutatum, including acervuli and conidia a. Front of the Mycelium b. Back of the Mycelium c. Acervuli d. Conidia. Scale bar: $a=1 \mathrm{~cm} \mathrm{~b}=1 \mathrm{~cm} \quad c=100 \mu \mathrm{m} \mathrm{d}=10 \mu \mathrm{m}$

Amplification of the ITS region of ribosomal DNA (rDNA) with the primers ITS1/ITS4, amplified a fragment of $\sim 600 \mathrm{pb}$, for $C$. acutatum and Botrytis cinerea. The entire ITS region measured from 600 to 800 bp and can be amplified easily with universal primers. Ms547 primers amplified a product of $\sim 900 \mathrm{pb}$.

According to the analysis in the web interface Blast, the sequences obtained from the isolates of the pathogens turned out to be Colletotrichum acutatum (theleomorph Glomerella acutata) and Botrytis cinerea (theleomorph Botryotinia fuckeliana) with an identity percentage between 98-100\% in GenBank database (Figure 1). 

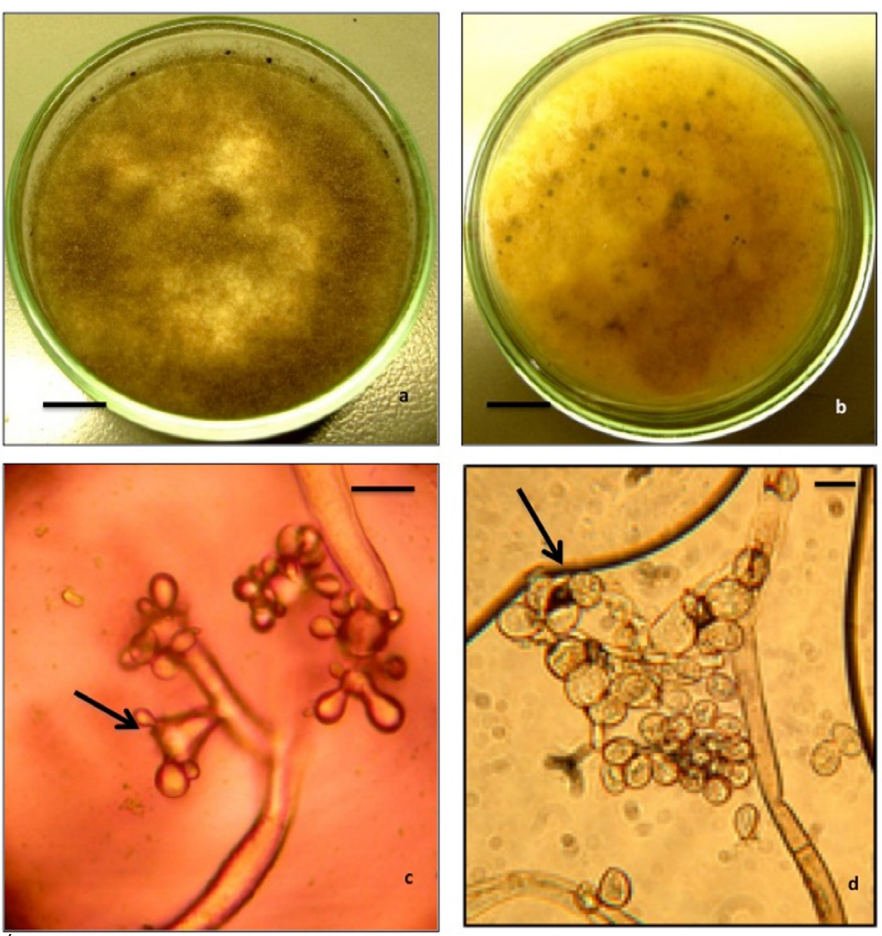

Figure 2. Morphologic structure of $B$. cinereal, including the conidiophores and conidia. a. Front of the Mycelium b. Back of the Mycelium c. Conidiophores d. Conidia Scale bar: $a=1 \mathrm{~cm} \mathrm{~b}=1 \mathrm{~cm} \quad c=10 \mu \mathrm{m} d=10 \mu \mathrm{m}$

The nucleotide sequence amplified with ITS1/ITS4 primers confirmed a $99 \%$ identity of the agent that was isolated from tomato to $C$. acutatum theleomorph state of Glomerella cingulata.

The nucleotide sequence amplified with ITS1/ITS4 primers and MS547 primers for Botrytis cinerea was identified in the GenBank database with a maximum of $100 \%$ and $97 \%$ identity respectively, asserting that the agent isolated from strawberry tissue was Botrytis cinerea but not Botrytis pseudocinerea. These results demonstrate that the rDNA analysis is a reliable method for taxonomic species identification (Screenivasaprasad et al. 1996; Freeman et al. 2000).

\section{In vitro inoculation of Cattleya maxima Lindl plants with patho- genic fungi}

Pathogenicity tests confirmed the presence of Colletotrichum (Figure. 3) (Figure.4) and Botrytis pathogens, showing the characteristic symptoms of each of the pathogens (Figure.5).
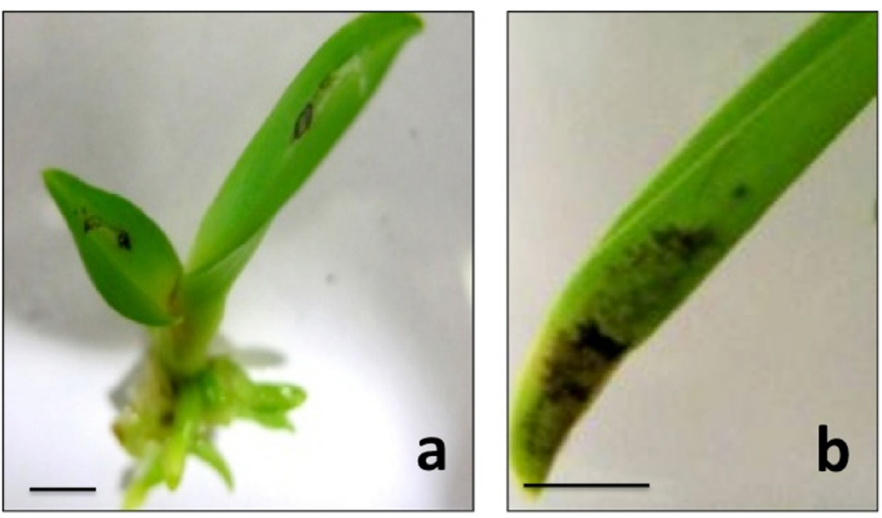

Figure 3. C. maxima inoculated with $C$. acutatum. a. General view Cattleya maxima inoculated with $C$. acutatum $\mathrm{b}$. apex with disease symptoms Scale bars $a=1 \mathrm{~cm} \mathrm{~b}=1 \mathrm{~cm}$

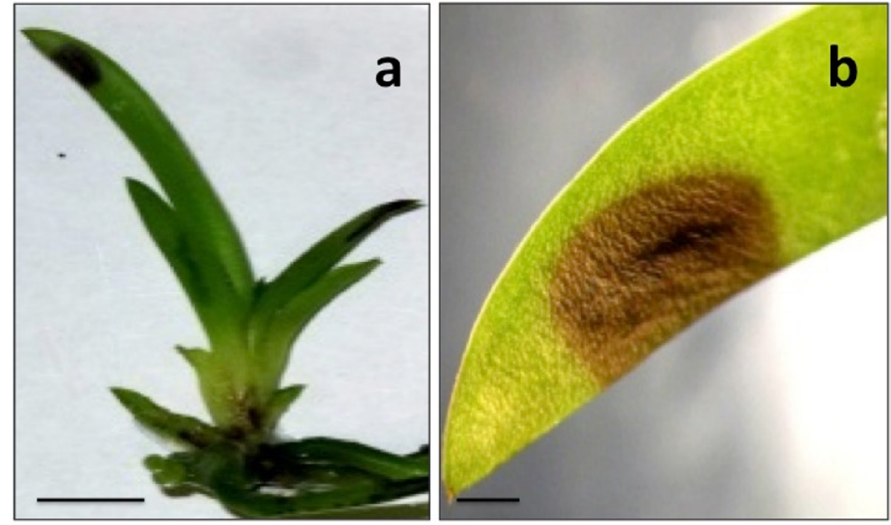

Figure 4. C. maxima inoculated with $B$. cinerea a. General view Cattleya maxima inoculated with $B$. cinerea $b$. apex with disease symptoms. Scale bars $a=1 \mathrm{~cm} \mathrm{~b}=5 \mathrm{~mm}$

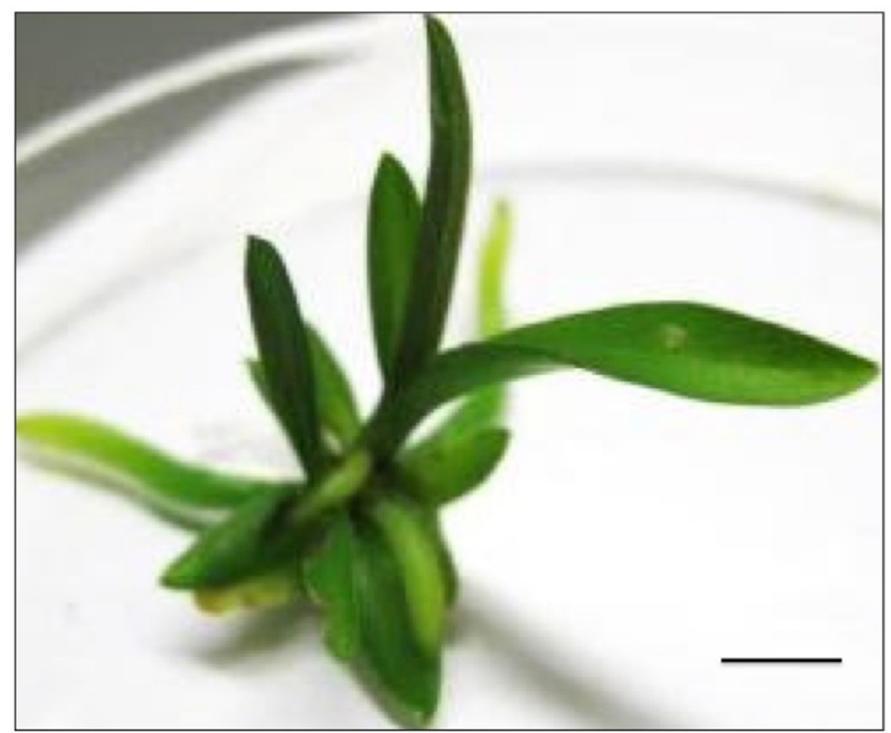

Figure 5. Cattleya maxima control. Scale bar $=1 \mathrm{~cm}$

\section{SERK gene expression in response to attack by pathogen fungi in Cattleya maxima Lindl.}

Resistant plants have the ability to recognize a pathogen invasion because they are molecularly equipped with an alert signaling system (Sessa et al. 2000). Several components are involved in this signaling event. The first is a unique receptor protein that is located either at the outer limits of the plant cell or within the cytosol. Other components include proteins that are responsible to transduce the signal to the nucleus where the induced expression of defense genes is activated (Tomas-Grau et al. 2019), included within this group the SERK gene.

\section{SERKs, as a group of LRR-RLKs, play important roles in the re- cognition of pathogens that activate effective defense responses.}

In this study, we evaluated the CMSERK gene expression facing pathogenic fungi attack in Cattleya maxima plants. The Real - Time Quantitative PCR analysis revealed that the fungal infection, It is related to gene expression CmSERK. In plants, there are numerous receptor-like kinases (RLKs), which they are involved in perceiving the external pathogenic signals and transferring the signals inside plant cells to activate a large number of gene expressions (Becraft 1998). 


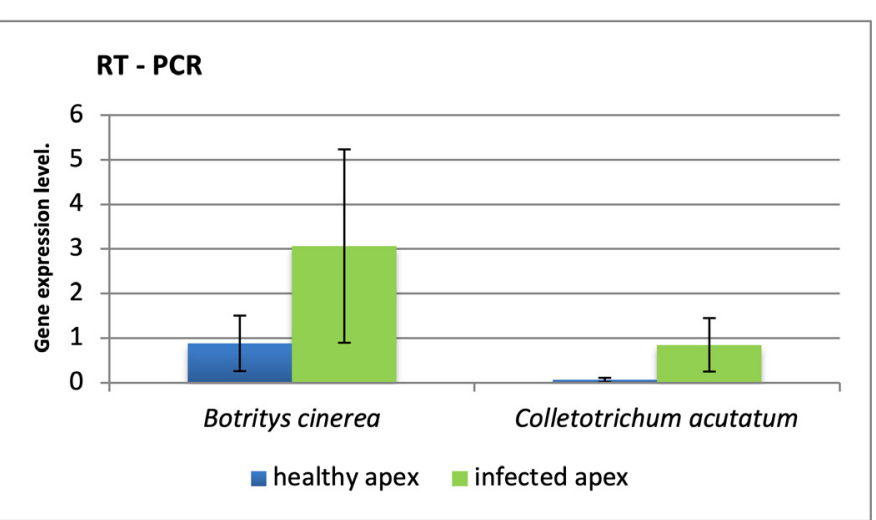

Figure 6. CMSERK gene expression in response to the attack of pathogen fungi. Results shown are means \pm standard error of 2 biological repeats.

The data presented in Fig. 6 indicated that tissues infected with Colletotrichum acutatum and Botrytis cinerea led to increase CMSERK gene expression, as compared with healthy tissue. These results are presented similar to the results reported by Hu et al. (2005) who found that OSSERK1, a newly identified rice SERK gene, was induced by pathogen infection and by defense signaling molecules such as salicylic acid, jasmonic acid, and abscisic acid. The constitutive overexpression of OsSERK1 in the transgenic rice plants led to an increase in host resistance to the blast fungus Magnapothe grisea.

Moreover, lettuce plants exhibited LSSERK gene silencing, showed reduced ability and became more susceptible to Sclerotinia attack. Thus, the elimination of $L S S E R K$ via RNA silencing corroborates the hypothesis that SERK is involved in plant defense, since these plants had to resist fungus attack (Santos et al. 2008).

The SERK genes belong to a small family of five plant receptor kinases that they are involved in at least five different signaling pathways. One member of this family, BRASSINOSTEROID INSENSITIVE1 (BRI1)-ASSOCIATED KINASE1 (BAK1), also known as SERK3, It is the coreceptor of the brassinolide (BR)-perceiving receptor $\mathrm{BR} 1$ 1, a function that is $\mathrm{BR}$ dependent and partially redundant with SERK1. BAK1 (SERK3) alone controls plant innate immunity, It is also the coreceptor of the flagellin receptor FLS2, and, together with SERK4, they can mediate cell death control (Hecht et al. 2001).

\section{CONCLUSIONS}

In conclusion, SERK gene in addition to being involved in developmental pathways such as somatic embryogenesis also plays an important role against pathogen infection in Cattleya maxima. In our study it was determined that CMSERK gene expression was stronger in infected tissue by fungal suspension, supporting that this gene is involved in signalling pathways of the plant, when attacked by pathogens.

\section{REFERENCES}

Altschup, S. F., Gish, W., Miller, W., Myers, E., y Lipman, D. 1990. Basic Local Alignment Search Tool. Journal of Molecular Biology, 215, 403-410.

Barnett, H y Hunter, B. 1998. Illustrated Genera of Imperfect Fungi. 4th Edition, APS Press, St. Paul. The American Psychopathological Society. Pp. 188-189.

Becraft P.W. 1998. Receptor kinases in plant development. Trends Plant. 1998; Sci 3:384-388
Bigeard, J.1., Colcombet, J.1, Hirt H. 2015. Signaling mechanisms in pattern-triggered immunity. Mol Plant. 8(4):521-39. https://doi. org/10.1016/j.molp.2014.12.022

Cannon, P.F., Damm, U., Johnston, P.R., Weir, B. S. 2012. Colletotrichum current status and future directions. Studies in Mycology 73, 181-213. https://doi.org/10.3114/sim0014

Cueva, A., Concia, L., Cella, R. 2012. Molecular characterization of a Cyrtochilum loxense Somatic Embryogenesis Receptor-like Kinase (SERK) gene expressed during somatic embryogenesis. Plant Cell Rep, Volume 31, Issue 6. Pp. 1129 - 1139.

Cueva-Agila, A.Y., Alberca-Jaramillo, N., Cella, R. and Concia, L. 2020. Isolation, phylogenetic analysis, and expression of a Somatic Embryogenesis Receptor like Kinase (SERK) gene in Cattleya maxima Lindl. Current Plant Biology. Volume 31 https://doi.org/10.1016/j.cpb.2020.100139

Dodson, C., Luerand, C. y Gustavo L. 2004. Orchids of Ecuador. Quito - Ecuador: Soluciones Gráficas D Yg.

Hecht, V., Velle-Calzada, J.P., Hartog, M.V., Schmidt, E.DL, Boutilier K, Grossniklaus U, de Vries SC. 2001. The Arabidopsis somatic embryogenesis receptor kinase 1 gene is expressed in developing ovules and embryos and enhances embryogenic competence in culture. Plant Physiol. 127: 803-816. https://doi. org/10.1104/pp.010324

Hou, C. y Yang, C. 2009. Functional Analysis of FT and TFL1 Orthologs from Orchid (Oncidium Gower Ramsey) that Regulate the Vegetative to Reproductive Transition. Plant and Cell Physiology, 50 (8)., pp. 1544-1557. https://doi.org/10.1093/pcp/pcp099

Hu, H., Xiong, L., Yang, Y. 2005. Rice SERK1 gene positively regulates somatic embryogenesis of cultured cell and host defense response against fungal infection; Planta 222:107-117. https:// doi.org/10.1007/s00425-005-1534-4

Latorre, B.A.; Agostín, E.; San Martín, R.; Vázquez, G.S. 1997. Effectiveness of conidia of Trichoderma harzianum produced by liquid fermentation against Botrytis bunch rot of table grape in Chile. Crop Protection.; 16: 209- 214.

Pfaffl, M.W. 2001 A new mathematical model for relative quantification in real-time RT-PCR. Nucleic Acids Res 29(9): e45.

Prihastuti, H., Cai, L., Chen, H., Mckenzie, E.H.C. and Hyde K.D. 2009. Characterization of Colletotrichum species associated with coffe berries in northen Thailan. Fungal Diversity. 89-109

Santos, M.O., Romano, E., Vieira, L.S, Baldoni,A.B, Aragão, F.J.L. 2008. Suppression of SERK gene expression affects fungus tolerance and somatic embryogenesis in transgenic lettuce. Plant Biol. doi:10.1111/j.1438-8677.2008.00103.x.

Schmidt, E.D., Guzzo, F., Toonen, M.A., De Vries, S.C. 1997. A leucine-rich repeat containing receptor-like kinase marks somatic plant cells competent to form embryos. Development. 124(10):2049-62. PMID: 9169851.

Sessa, G. and Martin, G. 2000. Protein Kinases in the Plant Defense Response. Advances in Botanical Research, 32:379-404. https://doi.org/10.1016/S0065-2296(00)32030-4

Tomas-Grau, R., Di Pieto, P.,., Chalfoun, N.., Grellet-Bournonville, C., Martos GG., debes M., Arias M E., Diaz-Ricci J., 2019. Colletotrichum acutatum M11 can suppress the defence response in strawberry plants. Planta D0l: https://doi.org/10.1007/s0042 5-019-03203-5

Walker, A.-S., Gautier, A., Confais, J., Martinho, D., Viaud, M., Le Pêcheur, P., Dupont, J., and Fournier, E. 2011. Botrytis pseudocinerea, a new cryptic species causing gray mold in French vineyards in sympatry with Botrytis cinerea. Phytopathology 101:14331445. https://doi.org/10.1094/PHYTO-04-11-0104 
Wan WL, Fröhlich K, Pruitt RN, Nürnberger T, Zhang L 2019. Plant cell surface immune receptor complex signaling. Curr Opin Plant Biol.15(50):18-28. https://doi.org/10.1016/j.pbi.2019.02.001.

White, T.J., Bruns, T., Lee, S., and Taylor, J. 1990. Amplification and direct sequencing of fungal ribosomal RNA genes for phylogenetics, in PCR Protocols: a Guide to Methods and Applications, eds. M. A. Innis, D. H. Gelfand, J. J. Sninsky, and T. J. White. San Diego, USA: Academic Press, https://doi.org/10.1007/s10658016-1009-4

Wit, P. 2007. How plants recognize pathogens and defend themselves. Cell Mol Life Sci. 64: 2726 - 2732. https://doi.org/10.1007/ s00018-007-7284-7

Wu S, Shan L, He P. 2014. Microbial signature-triggered plant defense responses and early signaling mechanisms. Plant Sci. 228C.118126. https://doi.org/10.1016/j.plantsci.2014.03.001 